\title{
ANALYSIS OF THE EFFECTS OF GOVERNMENT POLICY AND THE INVOLVEMENT OF STAKEHOLDERS ON THE PERFORMANCE OF MSMES
}

\author{
Sri Harini ${ }^{(1)}$ \\ Sudarijati $^{(2)}$ \\ Apendi Arsyad ${ }^{3)}$ \\ ${ }^{(1),(2)}$ Management Studies Program, Faculty of Economics, Djuanda University \\ ${ }^{(3)}$ Agribusiness Studies Program, Faculty of Agriculture, Djuanda University \\ email: sri.harini@unida.ac.id
}

\begin{abstract}
ABSTRAK
Usaha Mikro, Kecil, dan Menengah mempunyai peran penting terhadap pembangunan nasional, sehingga perlu mendapat perhatian pemerintah dan masyarakat. Tujuan penelitian ini adalah untuk mengetahui pengaruh kebijakan pemerintah (Pusat dan Daerah), dan keterlibatan stakeholders (lembaga pendidikan, lembaga keuangan, koperasi, asosiasi usaha, dan Lembaga Swadaya Masyarakat) terhadap kinerja UMKM. Penelitian menggunakan metode kuantitatif, analisis koefisien regresi dan korelasi. Hasil penelitian menunjukkan pemerintah telah memberikan perhatian khusus terhadap UMKM melalui UU No. 20 tahun 2008 dan peraturan pemerintah pusat dan daerah melalui dinas koperasi dan UMKM. Keterlibatan stakeholders dalam pelatihan, pembinaan, pendampingan, pendanaan, dan kemitraan mempunyai peran penting terhadap kinerja UMKM. Harapan UMKM pemerintah memperbaiki Undang-undang dan peraturan seperti pajak murah, birokrasi dan administrasi yang mudah, sehingga lebih kompetitif serta keterlibatan stakeholders terhadap pemberdayaan UMKM secara berkelanjutan.
\end{abstract}

Kata kunci: kebijakan, keterlibatan, kinerja.

\begin{abstract}
Micro, Small, Medium and Enterprices (MSMEs) have an important role to national development, so it needs to get the attention of government and society. This study aims to assess the effect of government policy and the involvement of stakeholders (educational institutions, financial institutions, cooperatives, business associations, and NGOs) on the performance of MSMEs. This study uses a quantitative method, regression and correlation analysis. Results show that the government has paid special attention to MSMEs through Law No. 20 of 2008, as well as through the Cooperative and MSMEs service office. Involvement of stakeholders in training, coaching, mentoring, funding, and partnerships have played an important role in improving of MSMEs performance. MSMEs hope that the government would amend laws and regulations, such as low taxes, simple bureaucracy and easy administrative procedures would also assist their competitiveness. MSME also needs sustainable involvement of stakeholders for their empowerment.
\end{abstract}

Keywords: policy, involvement, performance.

\section{INTRODUCTION}

The current globalization of production is unprecedented with the production of goods and services becoming increasingly fragmented across enterprises and countries. Large and multinational companies (LMNCs) in OECD countries clearly lead this process, but small and medium-sized enterprises (SMEs) - their traditional partners, suppliers and distributors - are also confronted by the diverse opportunities and challenges that arise from the new production context (OECD, 2008).

To develop micro, small, and medium enterprises (MSMEs), the Indonesian government and the legislature enacted Law No. 20 of 2008 on
MSMEs. Article 3, of this law states that the objective of MSMEs is to develop and expand, which, in turn will improve the national economy based on equitable economic democracy. This is in line with Article 33 of the 1945 Indonesian Constitution particularly Article 1, which states that the economy will be organized as a common endeavour based upon the principle of the family system. In other words, the economy is from the people, for the people, and by the people. Therefore, to develop the national economy, all business units, large and small, have to participate actively. Future more, MSMEs need to be empowered and developed. 
Article 5 of Law No. 20 of 2008, defines the aim of empowering MSMEs as to: 1). Create a balanced, developed, and equitable national economic structure; 2). grow and develop the capabilities of MSMEs to make them as strong and independent enterprises; 3 ). improve the role of MSMEs in regional development, employment creation, income distribution, economic growth, and poverty eradication. MSMEs play an important role in reducing poverty. The level of poverty in Indonesia is still high and action needs to be taken to prevent it from becoming worse.

To strengthen MSMEs, the government has passed regulations and policies covering various aspects including 1) funding, 2) facility and infrastructure, 3) business information, 4) partnerships, 5) business permit,s 6) business opportunities, 7) trade promotion, and 8) institutional support. Developing a conducive business climate, however, is not just the responsibility of government but also of he business community and the general community.

MSMEs play an important role in Indonesia's economic development through employment creation and public prosperity improvement. The role of MSMEs can be seen from their position as 1) the main actors in economic activities in a number of sectors, 2) the largest employment providers, 3) important actors in the development of local economic activities and public empowerment, 4) new market creators and sources of innovation, and 5) maintainers of balanced payment through export activities. The role of MSMEs in the national economy is so strategic that they must be the focus of the national economic development in the future.

The role of banks in the development of small and medium business in the province of Daerah Istimewa Yogyakarta (DIY) was very important, (Susilo, 2010). This was because the role of nonbank credit and financial institutions in the financing of small and medium business was still relatively low. In general the role of banks in intervening in the empowerment of SMEs is very helpful in the establishment, expansion and development of businesses thus, in turn, providing more employment opportunities. These opportunities must also be accompanied by an increase in qualified human resources, to ensure a highly competitive workforce, which will ultimately increase revenue, (Siswanto, 2011).

Studies by Herawati and Sofhani (2014), on the innovation and linkages between actors in the Center of Metal Ngingas Sidoarjo Regency concluded that a large number of entrepreneurs have been still linked to large companies in the chain of production and marketing. Nevertheless, building links with large companies, is quite difficult for employers SMEs in the Center of Metal Ngingas Sidoarjo Regency, for example, they found it hard to follow the standards set by the large companies. The links between employers from the Center of Metal Ngingas Sidoarjo Regency with other actors namely (such as, government, employers, universities / research institutions / business development institutions and financial institutions or banks), are still weak.

Harini (2011a; 2011b; 2012), revealed the factors, which influence the performance of MSMEs, there are attitude, mentality, and management abilities. It will be effect to profit MSME's. Management training and entrepreneurship would influence the performance of MSMEs.

Stakeholder engagement is critical to empower MSMEs. MSMEs stakeholders, include government agencies, educational institutions, NGOs, cooperatives, banks and business associations. To date there has been in sufficient interaction between the various stakeholders. It is expected that pro MSMEs policies created by central and local governments through laws and government regulations will assists in creating competitive MSMEs. Although, the number of MSMEs has increased, this increase is small and the number of MSMEs does fluctuate from year to year. This is probably caused by inadequate government policy and involvement of stakeholders in the development of MSMEs. Study by Soares, et.al. (2014), however shows that government policy does not have direct or moderating effect on the improve SMEs performance.

This study assesses the development and empowerment of MSMEs: identifies the policies (central and local government); and the involvement of other stakeholders (educational institutions, NGOs, banks, cooperatives, and business associations). This study also determines supporting and constraining factors in the empowerment of MSMEs and assesses the impact of the role of government and the involvement of stakeholders on MSMEs performance.

Considering the strategic role of MSMEs, it is important that they are empowered to grow and develop into strong and independent enterprises. Law No. 20 of 2008 on MSMEs defines, empowerment as "activities by central government, local government, business community, and the public in ordering together to create conducive business climate and develop business".

According to the Indonesian Central Bureau of Statistics (BPS), a company employing 1-4 people is classified as a home industry, 5-19 employees as a small industry, 20-99 employees as a medium 
industry, and more than 100 employees as a large industry.

Law No. 9 of 1995, defines micro, small, and medium enterprises as follows: (1) Micro/home industry is an industry/business activity which has an asset value of up to 50.000.000 IDR (3,764 USD) excluding land and buildings; (2) Small industry/ business is an enterprise conducting business activity in industry with an investment value of 50.000 .000 IDR (3,764 USD) excluding land and buildings; (3) Medium industry/business is an enterprise conducting business activity in industry with an investment value of between 50.000.000 IDR (3,764 USD) and 1.000.000.000 IDR (752,708 USD), excluding land and buildings.

Local government can empower MSMEs by passing appropriate regulations. For example, corrupt officials may impose a number of permits, which are expensive to obtain. If local government could overcome these problems, it would be very helpful for the MSMEs to get rid of these internal and external constraints. Kuswara (2013) conducted a study on the effect of the implementation of policy on business credit and MSME development, business management and productivity. His study used a qualitative approach on the basis of causaleffectual model analysis and showed that the implementation of policy about people's business credit and MSME development provided significant positive effect on business management and productivity.

Another study by Handriani (2011) examined 60 micro businesses, using four dependent variables and one independent variable. Results of Handriani's study showed that internal and external factors, business people's skills, strategy, and ethos had significant effects, both partially and simultaneously, on competitive advantages applied by micro business operators in the Semarang Regency.

A study by Irdayanti (2012) on the role of the government in the development of MSMEs found that the "governments' synergy in their attempt to boost the upgrading of pottery in Kasongan using local economic development programs. This synergy can be seen from the craftsmanship policy in which the public and the private sector such as individuals, universities, and banks were involved as a (joint venture) to enhance the upgrading in the effort of gaining the global market. The upgrading concept was a part of Global Value Chain analysis as a method in examining the added value gained from the product distribution in the global market. Results of this research showed that Kasongan's pottery industry center was capable in performing three upgrading processes, namely design upgrading, labor upgrading using labor development, and also marketing upgrading by developing some galleries. This could be seen from the absent of the synergy among the governments, privates, and public".

Factors affecting the performance of SMEs in Bogor Regency (Harini, 2011) included entrepreneurship mentality, marketing management capability, entrepreneurship attitudes, human resources management capability, and operational management capability, respectively. Support for MSMEs in Bogor Regency, included supports from academics through coaching, training and mentoring; sharia financial institutions with soft financial support schemes, institutions or companies through Corporate Social Responsibility schemes in the form of partnership, coaching, and development; and government support through policies conducive for and favorable to MSMEs.

In general, results of this study were in line with those of previous studies (Sulistio dan Mansur, 2010, Okpara, 2011; Adawiyah, 2012) which suggested that problems commonly faced by MSMEs in their business development were weak financial planning, poor management, illegal business practices (collusion and corruption), inadequate facilities and infrastructure, poor accounting, weak networks, difficulty in accessing markets, non-conducive business climate. These problems were classified into internal and external factors.

\section{METHODS}

This study focused on MSMEs in Greater Bogor Area (Bogor City and Bogor Regency). Bogor City has a population of 820,707 distributed in six districts, namely South Bogor, East Bogor, North Bogor, Central Bogor, and Tanah Sereal. Bogor City was selected because it is seen as a City of Trade with productive human resources and prime service. Bogor Regency covers an area of 298,838,304 Ha divided into 40 districts. The population size and location close to the capital city have given positive economic opportunities to Bogor City and Bogor Regency. The study was conducted from March to October 2015.

This study used a descriptive qualitative approach to achieve the objective of the first year of study, namely to identify government policy and the involvement of stakeholders in the empowerment of MSMEs and to analyze supporting and constraining factors in the empowerment of MSME in the Greater Bogor Area. A descriptive correlation analysis was used to assess the effects of government policy and the involvement of stakeholders in the empowerment of MSMEs and to design a model of MSMEs empowerment, based on people economy and focusing on exports. 
This study examined 35,572 business people of MSME's in Bogor City and 10,000 business people of MSMEs in Bogor Regency. Considering the high number of MSME in the Greater Bogor Area, a Slovin sampling technique (Umar, 2011) was used to determine the number of targets (200 units). A stratified random sampling technique was used to ensure that the selected targets were proportionally distributed in 6 districts in Bogor City and 40 districts in Bogor Regency.
Primary data were collected through observation, interviews, and questionnaires. Secondary data were obtained from a literature survey (text books, journals, and scientific reports). Data analyses were initiated by classic assumption tests (normality, multicollinearity, heteroscedasticity, and autocorrelation). Data were subjected to both qualitative and quantitative analyzes. Qualitative analysis was done to assess government policy and the involvement of stakeholders in MSME empowerment.

Table 1. Operational and Measurement of Variables

\begin{tabular}{|c|c|c|}
\hline Variable & Dimension & Indicator \\
\hline \multirow{11}{*}{ Policy } & \multirow{4}{*}{ Central Government } & Investment policy \\
\hline & & Access to productive resources \\
\hline & & Economic policy (the exchange rate) \\
\hline & & Credit of interest rate policy \\
\hline & \multirow{7}{*}{ Local Government } & Facilities (roads, electricity, telephone, water) \\
\hline & & Central/group Businesses \\
\hline & & Marketing \\
\hline & & Financial \\
\hline & & Retribution \\
\hline & & Tax rate \\
\hline & & Trade licenses \\
\hline \multirow{19}{*}{ Stakeholders Involvement } & \multirow{4}{*}{ Education institution } & Training \\
\hline & & Mentoring \\
\hline & & Coaching \\
\hline & & Research \\
\hline & \multirow{3}{*}{ Financial Institution } & Socialization \\
\hline & & Financing \\
\hline & & Mentoring/Coaching \\
\hline & \multirow{2}{*}{$\begin{array}{l}\text { Non-Government } \\
\text { Organization }\end{array}$} & Research \\
\hline & & Coaching \\
\hline & \multirow{6}{*}{ Cooperative } & Inti Plasma $^{1}$ \\
\hline & & Sub-contracting \\
\hline & & Franchising \\
\hline & & Trading \\
\hline & & Distribution/Agency \\
\hline & & Joint venture/outsourcing \\
\hline & \multirow{4}{*}{ Industry Association } & Partnership \\
\hline & & Material \\
\hline & & Marketing \\
\hline & & Financing \\
\hline \multirow{5}{*}{ SME Performance } & \multirow{3}{*}{ Financial } & Sales \\
\hline & & Profit \\
\hline & & Capital \\
\hline & \multirow{2}{*}{ Non-Financial } & Labor \\
\hline & & Productivity \\
\hline
\end{tabular}

Quantitative analysis to assess the effects of the government policy and the involvement of stakeholders on MSME empowerment using a series of statistical tests including correlation, determination, regression, and significance tests (Sugiyono, 2013).

\section{RESULTS AND DISCUSSION MSME Development}

Data of Ministry of Cooperatives and MSMEs (2013) showed that $1,361,129$ of MSMEs $(2.41 \%)$ which employed 6,486,573 $(6.03 \%)$ people in 20122013. The contribution of MSMEs to constant-price GDP in 2012-2013 was 85,458.5 billion IDR (5.89\%).

The role of MSMEs as employers, their contribution to GDP in 2012-2013 increased from previous years (BPS, 2014). This indicated that MSME's played an important role in solving unemployment and improving the income and welfare of the Indonesian people. In 2013 in the Bogor Regency there were 13,400 MSME units spreading over 40 districts. Items produced by 24 
production centers included bags, shoes, jackets, clothing, and sweet toffee-like confection (dodol), and dried flowers. Overall, the number of MSME units in six districts in Bogor City decreased by $1.9 \%$. The number of people employed (904) increased by $4.8 \%$ because some business units employed more staff.

\section{Legislation and Policies in MSME's Field}

Government has made legislation and policies related to MSME. included developing and passing. Law No. 20 of 2008 on MSMEs, Article 3 of this law defines the objective of MSMEs as 'to make their business grow and expand in order to develop the national economy based on equitable economic democracy'. This is similar to Article 33 of the 1945 Constitution, Paragraph 1, which states that 'the economy shall be organized as a common endeavor based upon the principle of the family system'.

According to Article 5 of Law No. 20 of 2008, the empowerment of MSME is aimed at: 1). creating the balanced, developed, and equitable national economic structure; 2). growing and developing MSME capability to make them as strong and independent enterprises; and 3). improving the role of MSME in regional development, employment creation, even income distribution, economic growth, and poverty eradication.

To implement Law No. 20 of 2008, the government has enacted Government Regulation No. 17 of 2013 on Micro, Small, and Medium Enterprises (MSME')s. In Article 2 states that Central and Local Government have the responsibility to assist MSMEs through activities to develop business, partnerships, and permits.

Central and local governments are facilitating production and processing; marketing and human resources; and design and technology. The development of MSMEs is conducted through such activities as: a). creation of an inventory and identifying potential and existing problems; b). preparation of coaching and development programs based on the potential and existing problems found in the survey; c). implementation of a coaching and development program; and d. monitoring and controlling the implementation of the program. These activities are done by using cooperative, center, cluster, and group approaches (Bogor Trading and Industry Institutions, 2014).

The priorities for the development of MSMEs as stipulated in the government regulation, include: a). giving opportunity to take part in procurement of goods and services in the central and local governments; b). reserving businesses for SMEs through limiting large businesses; c). simplifying permits; d). facilitating finance, in accordance to prevailing regulations; or e). facilitating technology and information.

In addition, the priority of large enterprises in the development of MSMEs is stipulated to include: a). business attachment; b). potential production of goods and services in the domestic market; c). production and supply of goods to satisfy basic needs; d). products with export potential; e). products with added value and competitive power; f). products with the potential to take advantage of technological advancement; and/or g) Potential new entrepreneurs. The stipulation of these priorities is expected to improve the function of MSMEs through clear and effective guidelines.

Meanwhile, MSMEs are developing their businesses by a) Developing business networks and partnerships; b) Doing business efficiently; c) Developing innovation and market opportunities; d) Enlarging marketing access; e) Utilizing technology; f) Improving product quality and finding wider business financing sources. These will improve the competitive power of MSMEs so they can win markets and play an active role in the sustainable development of Indonesia's national economy.

To optimize the empowerment of MSMEs, the State Ministry of Cooperatives and MSMEs is developing cooperation with relevant institutions, provincial governments, and city/regency governments to conduct empowerment programs focusing on: (1) institutional empowerment of MSMEs; (2) improving of MSMEs access to financial sources; (3) streamlining production through selective business assistance, to stimulate growth; (4) developing of marketing networks; (5) training MSME staff; and (5) assessment, and research, into MSMEs.

To develop MSMEs, the Bogor Regency Government, represented by Service Office of Cooperatives, SMEs, and Industry and Trade has introduced the following vision, 'the realization of cooperatives, MSMEs, Industry, and Trade in Bogor Regency with Their Most Advanced Service to Improve Competitiveness by Prioritizing Quality and Quantity'. To realize its vision and mission, the Service Office of (Cooperatives, MSMEs, Industry and Trade has determined 16 programs and 129 activities (MSMEs institution in Bogor Regency, 2014).

Bogor City is a city with a significant number of MSME's. Out of 3200 MSME units in Bogor City, 700 are under guidance of the Service Office of Industry and Trade (Antaranews Bogor, 22 
Table 2. The Development of Micro, Small, and Medium Enterprises (MSME) and Large Enterprises (LE) in 2012 - 2013

\begin{tabular}{|c|c|c|c|c|c|c|c|c|}
\hline \multirow[t]{2}{*}{ No } & \multirow[t]{2}{*}{ Indicator } & \multirow{2}{*}{ Unit } & \multicolumn{2}{|c|}{ Year 2012} & \multicolumn{2}{|c|}{ Year 2013} & \multicolumn{2}{|c|}{$\begin{array}{l}\text { Development in } \\
2012-2013\end{array}$} \\
\hline & & & Number & $\begin{array}{l}\text { Share } \\
(\%)\end{array}$ & Number & $\begin{array}{l}\text { Share } \\
(\%)\end{array}$ & Number & $\%$ \\
\hline 1 & 2 & 3 & 4 & 5 & 6 & 7 & 8 & 9 \\
\hline \multirow[t]{6}{*}{1} & Business Unit $(\mathrm{A}+\mathrm{B})$ & (Unit) & $56,539,560$ & & $57,900,787$ & & $1,361,227$ & 2.41 \\
\hline & $\begin{array}{l}\text { A. Micro, Small and Medium } \\
\text { Enterprise (MSME) }\end{array}$ & (Unit) & $56,534,592$ & 99.99 & $57,895,721$ & 99,99 & $1,361,129$ & 2.41 \\
\hline & - Micro Enterprise (MiE) & (Unit) & $55,856,176$ & 98.79 & $57,189,393$ & 98,77 & $1,333,217$ & 2.39 \\
\hline & - Small Enterprise (SE) & (Unit) & 629,418 & 1.11 & 654,222 & 1,13 & 24,803 & 3.94 \\
\hline & - Medium Enterprise (ME) & (Unit) & 48,997 & 0.09 & 52,106 & 0,09 & 3,110 & 6.35 \\
\hline & B. Large Enterprise (LB) & (Unit) & 4,968 & 0.01 & 5,066 & 0,01 & 98 & 1.97 \\
\hline \multirow[t]{6}{*}{2} & Human resources $(\mathrm{A}+\mathrm{B})$ & (People) & $110,808,154$ & & $117,681,244$ & & $6,873,090$ & 6.20 \\
\hline & $\begin{array}{l}\text { A. Micro, Small and Medium } \\
\text { Enterprise (MSME) }\end{array}$ & (People) & $107,657,509$ & 97.16 & $114,144,082$ & 96,99 & $6,486,573$ & 6.03 \\
\hline & - Micro Enterprise (MiE) & (People) & $99,859,517$ & 90.12 & $104,624,466$ & 88,90 & $4,764,949$ & 4.77 \\
\hline & - Small Enterprise (SE) & (People) & $4,535,970$ & 4.09 & $5,570,231$ & 4,73 & $1,034,262$ & 22.80 \\
\hline & - Medium Enterprise (ME) & (People) & $3,262,023$ & 2.94 & $3,949,385$ & 3,36 & 687,363 & 21.07 \\
\hline & B. Large Enterprise (LB) & (People) & $3,150,645$ & 2.84 & $3,537,162$ & 3,01 & 386,517 & 12.27 \\
\hline \multirow[t]{6}{*}{3} & $\begin{array}{l}\text { Constant-Price GDP } 2000 \\
(\mathrm{~A}+\mathrm{B})\end{array}$ & $\begin{array}{l}\text { (Rp. Billion) } \\
\text { (Rp. Billion) }\end{array}$ & $2,525,120.4$ & & $2,670,314.8$ & & $145,194.4$ & 5.75 \\
\hline & $\begin{array}{l}\text { A. Micro, Small and Medium } \\
\text { Enterprise (MSME) }\end{array}$ & (Rp. Billion) & $1,451,460.2$ & 57.48 & $1,536,918.8$ & 57,56 & $85,458.5$ & 5.89 \\
\hline & - Micro Enterprise (MiE) & (Rp. Billion) & $790,825.6$ & 31.32 & $807,804.50$ & 30,25 & $16,978.9$ & 2.15 \\
\hline & - Small Enterprise (SE) & (Rp. Billion) & $294,260,736366$ & 11.65 & $342,579.19$ & 12,83 & $48,318.5$ & 16.42 \\
\hline & - Medium Enterprise (ME) & (Rp. Billion) & ,373.9 & 14.51 & $386,535.07$ & 14,48 & $20,161.1$ & 5.50 \\
\hline & B. Large Enterprise (LB) & (Rp. Billion) & $1,073,660.1$ & 42.52 & $1,133,396.05$ & 42,44 & $59,735.9$ & 5.56 \\
\hline
\end{tabular}

Source: Ministry of Cooperatives and SMEs (processed), 2013.

January 2015). Like the Bogor Regency Government, Bogor City Government is represented by the Service Office of Cooperatives and MSMEs which has also created policies and programs. Some activities which have been conducted are facilities MSME business activities by, for example, distributing capital assistance, providing coaching, expanding markets, simplifying permits, and giving assistance in halal certification.

MSME development and empowerment programs arranged by Service Office of Cooperatives and MSME's in Bogor City and Bogor Regency were, however, insufficient when compared to the amount of MSMEs in both Bogor City and Bogor Regency. There were many MSMEs which had no access to and had never been touched by activity programs from the service offices. This was one of the reasons why the number and performance of MSMEs did not develop as well as expected, and the government is now attempting to orient programs to the early phases of MSME businesses. Even the distribution of programs to all regions is important. A study by Suryana (2015) found that only $30 \%$ to $50 \%$ MSMEs survived 3 and 5 years.

\section{Involvement of Stakeholders}

The empowerment of MSME is not the responsibility of government alone. Other related stakeholders include educational institutions through their Tridharma activities (teaching, researching, and social activity); finance institutions with affordable loans and financing schemes; cooperatives with their MSME business programs; non-governmental organizations with activities to control and evaluate government policies; and business associations with Corporate Social Responsibility programs. These stakeholders are all expected to play active roles in MSME empowerment in Indonesia. Results obtained from interviews and questionnaires for distribution in this study are listed in Table 3.

There are some alternative strategies which can be used in the empowerment of MSMEs (Sriyana, 2010), namely simplifying access to capital; assisting infrastructure development; business scale development; developing human resources; improving access to technology; and creating a conducive business climate. Tambunan (2008) suggested that in developing countries like Indonesia, MSMEs are very important as they have three main characteristics which are different from those of large enterprises. They also have several advantages including (1) the number of small and micro enterprises is much higher than that of larger enterprises so that the economic advancement, especially in villages, is really affected by the 
advancement in MSME development; (2) MSMEs are highly labor intensive and therefore have high potential as employment creators, and the growth of MSMEs is particularly important in fulfilling the national policy on increasing work opportunities and creating income for people in poverty; and (3) MSMEs can be a starting point to increase savings/ investment in rural areas and, at the same time, this business group can function as a place for assessment and improvement of business capability for people in rural areas.

\section{Supporting and Constraining Factors of MSMEs Empowerment}

Although MSMEs face many problems in marketing, capital, human resources, management, and entrepreneur mentality, this study found that there were factors supporting the empowerment of MSMEs in Bogor City. For example MSMEs can help lower unemployment rates, which is one of the biggest problems in Indonesia. Increasing capacity of MSMEs not only improves the situation of the entrepreneur and employees but directly assists the strengthening Indonesia's economy. Although (Dharmayantie, and Fauzan, 2017), finding entrepreneurial characteristics has no significant effect on the performance of MSMEs.

The situation in Bogor City is similar to that of Medan, Lores (2014) indicated that there were difficulties in obtaining capital for production process equipment, cash availability for operational costs, limited skilled labor and marketing difficulties caused by a lack of a trusted sales force in footwear businesses in Medan. These problems could be overcome by central and local government introducing policies, such as credit provision with low interest rates, activities to increase the capabilities of MSME entrepreneurs and staff through technical training, and partnership programs with larger companies for product marketing.

In general, constraining factors in MSMEs empowerment can be divided into internal and external factors. There are three main internal factors. The first is limited capital which is the main constrain in the business development in MSMEs in Banyumas Regency, where most MSMEs use their own capital. Second, employees lack of formal education, knowledge, and skills significantly affects business management. Third, MSMEs have weak business networks and limited ability to penetrate the market because most are family businesses producing products which are of a less competitive product quality (Adawiyah, 2012).
The development of SMSE faces some constraints such as weak human resources managerial capability which can be categorized into two aspects, structural and cultural. Structural aspect includes weaknesses in company's structure such as weaknesses in managerial and organizational field, quality supply, technology adoption and mastery, difficulty in capital obtainment and limited access to market. Cultural aspect includes inadequate information access and other weaknesses in other requirements to get access to capital, marketing, and raw materials (Harjanto, 2010).

Meanwhile, there are six main external factors which constrain the empowerment of MSMEs. The first is a business climate which is not conducive to growth of MSMEs, because there are a limited number of governments which assist in their growth. Second, there are limited business facilities and infrastructure, and there is limited information about relevant developments in science and technology. Third, a number of fees are imposed on SMEs as a result of the Law No. 22 of 1999 on Regional Autonomy which give local government the power to regulate and protect local populations. Fourth, free trade agreements including Asia Free Trade Agreement (AFTA) of 2003, Asian Economic Community (AEC) agreement of 2015, and the APEC agreement of 2020 impose strict requirements for MSMEs to compete in free trade. SMEs must improve their production efficiency and produce products which are compliant to global market frequency and adhere to standards relating to quality (ISO 9000), the environment (ISO 14000), human rights, and labor conditions. These issues are often used by developed countries in an unfair way as a Nontariff Barrier to Trade. Accordingly, SMEs are expected to be completive with both comparative and competitive advantages. Fifth, most MSMEs products are subject to changes in fashion and craftsmanship, resulting in products with short lifespan. Sixth, access to the market is limited because less information, making it difficult for the causing the products they make to compete in national and international markets.

\section{Role of Stakeholders in MSME Performance}

The equation uses multiple linear regression analysis and correlation analysis, and shows the role of central government and local government policies, educational institutions, financial institutions, nongovernment organizations, cooperatives and business associations on the performance of SMEs in Bogor. 
Table 3. Empowerment Activity MSMEs in Bogor City and Bogor Regency

\begin{tabular}{|c|c|c|c|}
\hline No & Stakeholders & Involvement & Activity \\
\hline 1 & $\begin{array}{l}\text { Service Office of } \\
\text { MSME, Bogor City }\end{array}$ & $\begin{array}{l}\text { Provision of programs by } \\
\text { Local Government Work } \\
\text { Unit (LGWU) Service Office } \\
\text { of Cooperatives and MSMEs }\end{array}$ & $\begin{array}{l}\text { Improvement of MSME } \\
\text { human resources quality and } \\
\text { product expo/business } \\
\text { meeting }\end{array}$ \\
\hline 2 & $\begin{array}{l}\text { Service Office of } \\
\text { Cooperative and } \\
\text { MSME, Bogor } \\
\text { Regency (LGWU } \\
\text { Program) }\end{array}$ & $\begin{array}{l}\text { Realizing a balanced, } \\
\text { developed, and equitable } \\
\text { economic system. } \\
\text { Developing MSMEs into } \\
\text { strong and independent } \\
\text { enterprises. } \\
\text { Improving the role of } \\
\text { MSMEs in local } \\
\text { development, employment } \\
\text { creation, and local revenue } \\
\text { improvement, economic } \\
\text { growth, and poverty } \\
\text { eradication }\end{array}$ & $\begin{array}{l}\text { Training on technology } \\
\text { Regulation } \\
\text { Partnership with business } \\
\text { people through CSR } \\
\text { Product promotion/expos }\end{array}$ \\
\hline 3 & NGOs & $\begin{array}{l}\text { Cooperation with the } \\
\text { Ministry of Agriculture, } \\
\text { Ministry of Manpower, and } \\
\text { donor agencies to facilitate } \\
\text { the development of MSME in } \\
\text { various regions and } \\
\text { institutional and technical } \\
\text { assistance }\end{array}$ & $\begin{array}{l}\text { MSME development } \\
\text { Capacity building } \\
\text { (institutional) } \\
\text { Technical development } \\
\text { (production, management, } \\
\text { and marketing techniques) } \\
\text { Legal contract }\end{array}$ \\
\hline 4 & Business Association & Facilitator & $\begin{array}{l}\text { Training } \\
\text { Facilitation in access to } \\
\text { technology, human resources, } \\
\text { and markets }\end{array}$ \\
\hline 5 & Cooperative & $\begin{array}{l}\text { Training } \\
\text { Capital } \\
\text { Consultancy }\end{array}$ & $\begin{array}{l}\text { Training, consultancies, } \\
\text { funding }\end{array}$ \\
\hline \multirow[t]{3}{*}{6} & \multirow[t]{3}{*}{ Educational Institution } & Wider caring duties & $\begin{array}{l}\text { Training according to } \\
\text { competence } \\
\text { Mentoring } \\
\text { Free supervision and } \\
\text { consultation }\end{array}$ \\
\hline & & $\begin{array}{l}\text { Special MSME coaching by } \\
\text { the Institute of Research and } \\
\text { Community Service }\end{array}$ & Coaching \\
\hline & & $\begin{array}{l}\text { MSME coaching is done } \\
\text { partially/only certain } \\
\text { faculty/individual }\end{array}$ & $\begin{array}{l}\text { Training and coaching in } \\
\text { product diversification, } \\
\text { training in financial reporting }\end{array}$ \\
\hline 7 & Financial Institution & Leasing, Credit & $\begin{array}{l}\text { Credit limit of } \mathrm{Rp} 5 \text { million } \\
\text { to } 5 \text { billion with tenure of } 6 \\
\text { months to } 4 \text { years with quick } \\
\text { process }\end{array}$ \\
\hline
\end{tabular}

Source: Processed Data, 2015.

Table 4 that shows a regression equation to estimate the following models:

$\mathrm{Y}=-19.124+0.360 \mathrm{X} 1+0.185 \mathrm{X} 2+0.275 \mathrm{X} 3+$

$0.309 \mathrm{X} 4+0.223 \mathrm{X} 5+0.278 \mathrm{X} 6+0.428 \mathrm{X} 7+\varepsilon$

Based on the regression equation it is clear that the performance of SMEs would be increased, if there were an improvement in both central and local government policies to make them more aligned to the SMEs, and increased the involvement of stakeholders. The study conducted by Farsi (2014), used exploratory factor analysis which demonstrated six challenges in the order of importance, including policy and regulatory environment. 
Table 4. Regression Coefficients a

\begin{tabular}{|c|c|c|c|c|c|}
\hline \multirow[t]{2}{*}{ Model } & \multicolumn{2}{|c|}{$\begin{array}{c}\text { Unstandardized } \\
\text { Coefficients }\end{array}$} & \multirow{2}{*}{$\begin{array}{c}\begin{array}{c}\text { Standardized } \\
\text { Coefficients }\end{array} \\
\text { Beta }\end{array}$} & \multirow[t]{2}{*}{$\mathrm{T}$} & \multirow[t]{2}{*}{ Sig. } \\
\hline & $\mathrm{B}$ & Std. Error & & & \\
\hline Constant & $-19,124$ & 3,131 & 0,242 & $-6,108$ & 0,000 \\
\hline Central Government Policy $\left(\mathrm{X}_{1}\right)$ & 0,360 & 0,054 & 0,210 & 6,610 & 0,000 \\
\hline Local Government Policy $\left(\mathrm{X}_{2}\right)$ & 0,185 & 0,031 & 0,141 & 5,983 & 0,000 \\
\hline Educational Institutions $\left(\mathrm{X}_{3}\right)$ & 0,275 & 0,069 & 0,196 & 4,011 & 0,000 \\
\hline Financial Institutions (X4) & 0,309 & 0,054 & 0,129 & 5,756 & 0,000 \\
\hline Non-Government Organization (X5) & 0,223 & 0,059 & 0,232 & 3,762 & 0,000 \\
\hline Cooperatives (X6) & 0,278 & 0,045 & 0,258 & 6,224 & 0,000 \\
\hline Industry Association (X7) & 0,428 & 0,063 & & 6,821 & 0,000 \\
\hline
\end{tabular}

a. Dependent Variable: SME Performance (Y)

Sources: Primary data is processed, 2015.

Results of regression and correlation coefficient analysis showed that policies of government (central and local) and the involvement of stakeholders cooperative, business association, and non governmental organization) played a role in MSME performance in Bogor City and Bogor Regency (Table 5). (educational institution, financial institution,

Table 5.Analysis of Correlation Coefficient

Model Summary ${ }^{\mathrm{b}}$

\begin{tabular}{lccrr}
\hline Model & $\mathrm{R}$ & $\mathrm{R}$ Square & Adjusted R Square & Std. Error of the Estimate \\
\hline 1 & $.912^{\mathrm{a}}$ & .832 & .826 & 3.562 \\
\hline ।. Predictors: (Constant), $\mathrm{X} 1, \mathrm{X} 2, \mathrm{X} 3, \mathrm{X} 4, \mathrm{X} 5, \mathrm{X} 6, \mathrm{X} 7$ & &
\end{tabular}

Source : Processed primary data, 2015.

Eniola et.al. (2015), shows that the contribution of small and medium enterprises in a knowledgebased economic system is very important for the economic growth and development of a developing nation. The results of a study Hoetoro (2014), revealed that some types of inter-firm linkages are important to improve the performance of SMEs.

\section{CONCLUSIONS}

It was concluded that in general, the MSMEs sector was developing well, both at national and local levels, particularly MSMEs in Bogor City and Bogor Regency which experienced improvement in number, employment rate, and contribution to the GDP in 2010-2015. MSMEs policies of central and local government were identified and these included laws, governmental regulations, ministerial regulations, and regional regulations in the levels of province, Bogor City, and Bogor Regency represented by the Service Office of MSMEs not useful because the policies and practice were not consistence. The involvement of stakeholders (educational institutions, financial institutions, cooperatives, business associations, and NGOs) was useful although each stakeholder had a different level of involvement.

Factors which supported of MSMEs include the pro MSME policies of central and local government and balanced and sustainable involvement of stakeholders. Government and stakeholders were able to improve MSME performance.

We recommended the following action should be taken by central and local governments and stakeholders. First, MSMEs should be empowered through the involvement of stakeholders (educational institutions, financial institutions, cooperatives, business associations, and NGOs). Central and local government produces more policies which favor MSMEs. Stakeholders should also be involved in the coordination and sustainability of MSMEs through institutional links, training, financing, and partnership programs. Second, MSMEs would be greatly assisted by government policies which provide them with low taxation rates, simple beaurocracy and procedures.

\section{REFERENCES}

Adawiyah, W.R. 2012. Faktor Penghambat Pertumbuhan Usaha Mikro Kecil Menengah (UMKM). Studi di Kabupaten Banyumas.

Dhamayantie, Endang, dan Rizky Fauzan. Penguatan Karakteristik dan Kompetensi Kewirausahaan untuk Meningkatkan Kinerja UMKM. Jurnal Manajemen, Strategi Bisnis dan Kewirausahaan. Volume 11 No. 1 Tahun 2017.

Eniola, et. al. 2015. Small and Medium Scale Business Performance in Nigeria: Challenges faced from an intellectual capital perspective. International Journal of Research Studies in Management, 4(1): 59-71.

Farsi and Todhraee. 2014. Identification the main challenges of small and medium sized enterprises in exploiting of innovative opportunities (Case study: Iran SMEs). Journal of Global Entrepreneurship Research 4(4):1-15. 
Handriani, E. 2011. Analisis Faktor Daya Saing Di Kabupaten Semarang. Jurnal Dinamika Manajemen, 2(1): 17-25.

Hardjanto, Imam. 2010. Entepreneurship Kewirausahaan. Malang, Universitas Brawijaya.

Harini, S. Faktor-faktor yang Mempengaruhi Kinerja UKM Kabupaten Bogor. Jurnal Sosial Ekonomi, ISSN 1410 - 6531, Volume 12 Nomor 34, Juni 2011a.

___ _ Pengaruh Kemampuan Manajemen terhadap Laba Pengrajin Sepatu. Jurnal Sosial Humaniora, ISSN 2087-4928, Volume 2 Nomor 2:102-182, Oktober 2011b.

Harini, S. Erni Yuningsih, Sudarijati. Pengaruh Pelatihan Manajemen Keuangan, Manajemen Pemasaran, Manajemen SDM, Manajemen Produksi dan Kewirausahaan Terhadap Kinerja UKM. Prosiding Seminar Nasional Universitas Pendidikan Indonesia, 14-12-2012.

Herawati, Rina, Tubagus Furqon Sofhani. 2014. Mendorong Peran Perguruan Tinggi Dalam Meningkatkan Inovasi dan Keterkaitan antar Aktor di Sentra Industri Logam Ngingas. Jurnal Perencanaan Wilayah dan Kota 2 SAPPK V3N3. ITB : 693-698.

Hoetoro. 2014. Cooperation and Competition among Clustered MSEs in East Java. Gadjah Mada International Journal of Business Vol. 16, No. 3 (September-December 2014): 275-293.

Irdayanti. Peran Pemerintah dalam Pengembangan UKM Berorientasi Ekspor Studi Kasus: Klaster Kasongan dalam Rantai Nilai Tambah Global. Jurnal Transnasional Vol. 3 No. 2 Februari 2012.

Kuswara Ganjar Nugraha. Pengaruh Pelaksanaan Kebijakan Kredit Usaha Rakyat dan Pembinaan Usaha Mikro Kecil dan Menengah terhadap Manajemen Bisnis untuk Peningkatan Produktivitas Usaha. Jurnal Ilmu Sosial ISSN: 2301-4873, Vol. 01, No. 01, Jan 2013.

Lores, Linda, Dhian Rosalina, Warsani Purnamasari. 2014. Kajian Faktor-faktor Pendorong Eksistensi dan Penghambat Potensi Pengrajin Alas Kaki Kota Medan. Fakultas Ekonomika dan Bisnis Universitas Kristen Satya Wacana ( $3^{\text {rd }}$ Economics \& Business Research Festival : 356-371).

Okpara, J.O. 2011. Factors Constraining the Growth and Survival of SMEs in Nigeria Implications for Poverty Alleviation, Management Research Review, Vol. 34 No. 2, 2011:156-171.

Siswanto, Heru. 2011. Peran Perbankan Dalam Pemberdayaan UMKM Dan Pengaruhnya Terhadap Ketahanan Ekonomi Masyarakat
(Studi Di Bank Syariah Mandiri Cab. Kota Depok Prov. Jawa Barat). Thesis, S2 Ketahanan Nasional. Electronic Thesis and Dissertation (ETD). Universitas Gadjah Mada, Yogyakarta.

Soares, et.al. 2014. Effect of Entrepreneurial Orientation on Business Performance Moderated by Government Policy (Study on SMEs in Timor Leste). International Journal of Business and Management Invention. ISSN (Online): 2319 - 8028, ISSN (Print): 2319 - 801X. www.ijbmi.org Volume 3 Issue 8 Á August 2014 Á PP.64-71.

Sriyana, Jaka. 2010. Strategi Pengembangan Usaha Kecil dan Menengah (UKM): Studi Kasus di Kabupaten Bantul. Simposium Nasional. Menuju Purworejo Dinamis dan Kreatif.

Sugiyono. 2013. Metode Penelitian Bisnis. Bandung: Alfabeta.

Sulistio, J. dan Mansur, A. 2010. Policy Analysis and Design of Small and Medium Enterprises for Development Program, Conference Proceeding, The 11th Asia Pacific Industrial Engineering and Management System Conference.

Suryana. 2015. Kewirausahaan Kiat dan Proses Menuju Sukses. Jakarta: Salemba Empat.

Susilo, Y. Sri. Peran Perbankan dalam Pembiayaan UMKM di Provinsi DIY. Jurnal Keuangan dan Perbankan. Vol 14 No. 3 September 2010:467-478.

Tambunan, T. 2008. Masalah Pengembangan UMKM di Indonesia : Sebuah Upaya Mencari Jalan Alternatif. Bahan diskusi Forum Keadilan Ekonomi (FKE). Institute for Global Justice. Jakarta, 28 September 2008.

Umar, Husen. 2011. Riset Manajemen Sumber Daya Manusia. Jakarta : Gramedia Pustaka Raya.

Legislation

Constitution of the Republic of Indonesia, of the 1945 Micro Small and Medium Enterprises Act of 1995, Number 9.

Small and Medium Enterprises Act of 2008, Number 20.

Government Policy

Government Policy in MSME's Development, Cooperatives Micro Small and Medium Enterprises, Bogor Institutions, 2014.

Organization for Economic Co-Operation and Development (OECD). 2008. Executive Summary. Enhancing the Role of SMEs in Global Value Chains. 